\title{
EFISIENSI BAMBU AIR (Equisetum hyemale) SEBAGAI FITOREMEDIATOR KADAR BIOLOGICAL OXYGEN DEMAND PADA LIMBAH CAIR INDUSTRI TAHU DI DESA PREMBUN KECAMATAN TAMBAK KABUPATEN BANYUMAS TAHUN 2015
}

\author{
Andhyka Septyana Nugraha'), Hari Rudijanto Indro Wardono²) \\ Jurusan Kesehatan Lingkungan, Politeknik Kesehatan Kemenkes Semarang, \\ Jl.Raya Baturaden KM 12 Purwokerto, Indonesia
}

\begin{abstract}
Abstrak
Industri tahu merupakan salah satu jenis usaha industri rumahan (home industri) yang menghasilkan tahu dari bahan kedelai.Desa Prembun Kecamatan Tambak Kabupaten Banyumas terdapat 1 pabrik tahu. Rata-rata limbah cair yang dihasilkan setelah proses pembuatan tahu sebesar 360 liter/ hari dengan konsentrasi BOD 5 sebesar 15.611,56 mg/liter. Metode yang digunakan untuk menurunkan beban BOD 5 pada limbah tahu adalah metode Fitoremediator menggunakan tanaman Bambu air (Equisetum hymale) dengan media lahan basah buatan aliran bawah permukaan Subsurface Flow Wetlands. Tujuan penelitian adalah untuk mengetahui efisiensi Bambu air (Equisetum hymale) sebagai fitoremediator terhadap penurunan konsentrasi BOD $_{5}$. Penelitian ini menggunakan jenis penelitian Pre experiment dengan metode pre and post test design yang bermaksud untuk mengetahui ada atau tidak adanya perbedaan antara pemakaian tanaman Bambu air (Equisetum hymale) dengan media (Subsurface Flow Wetlands) terhadap penurunan konsentrasi BOD 5 .Hasil penelitian sebagai berikut debit influent 0,22 liter/menit dan debit effluent 0,020 liter/menit, parameter suhu influent 30, $2^{\circ} \mathrm{C}$ dan suhu effluent $26,1^{0} \mathrm{C}$, parameter

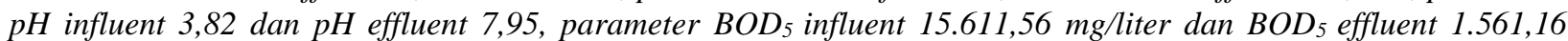
mg/liter dengan efisiensi penurunan sebesar 89,99\%. Hasil analisis statistik menggunakan uji paired t-test menghasilkan nilai signifikan ( $P$ Value) sebesar 0.000, yang artinya nilai sig ( $P$ value) $<\alpha(0.05)$ sehingga terdapat perbedaan yang signifikan. Kesimpulan dari penelitian ini adalah tanaman Bambu air (Equisetum hymale) dengan media (Subsurface Flow Wetlands) dapat menurunkan konsentrasi $\mathrm{BOD}_{5}$ dengan nilai penurunan yang signifikan.
\end{abstract}

Kata kunci : Bambu air, Fitoremediator, BOD 5

\begin{abstract}
Abtract
Tofu Industry is one of the home industry business that produces tofu from soy. There was 1 tofu industry in Prembun Sub-District, Tambak District Banyumas Regency. The average daily wastewater generated was 360 liters / day with $\mathrm{BOD}_{5}$ concentration $15611.56 \mathrm{mg} /$ liter. The method used to reduce the $\mathrm{BOD}_{5}$ level on wastewater was phytoremediator method using water bamboo plant (Equisetum hymale) with a wetlands media-made subsurface flow Subsurface Flow Wetlands. The research objective was to determine water bamboo the efficiency (Equisetum hymale) as phytoremediator to decrease the $\mathrm{BOD}_{5}$ concentration. The research design used was Pre and post test design, intended to determine the difference between the use of water Bamboo plant (Equisetum hymale) with media (Subsurface Flow Wetlands) to decrease the $\mathrm{BOD}_{5}$ concentration. The research result obtained shows influent debit 0,22 liter / min and effluent 0,020 liters / minute, 30.2 $\mathrm{C}$ temperature parameter influent and effluent temperature of $26.1^{\circ} \mathrm{C}$, the parameters influent $\mathrm{pH} 3.82$ and effluent $\mathrm{pH} 7.95, \mathrm{BOD}_{5}$ influent $15611.56 \mathrm{mg} /$ liter and $\mathrm{BOD}_{5}$ effluent $1561.16 \mathrm{mg} /$ liter with $89.99 \%$ decrease efficiency. The statistical analysis results using paired t-test obtained significant value ( $P$ Value) of 0,000, which means that the sig value (P value) $<\alpha(0.05)$, so there was significant differences. The conclusion from this study is the water bamboo plant (Equisetum hymale) with media (Subsurface Flow Wetlands) can lower the $\mathrm{BOD}_{5}$ concentration significantly.
\end{abstract}

Keyword : Water Bamboo, Phytoremediator, $\mathrm{BOD}_{5}$

\section{PENDAHULUAN}

Kesehatan lingkungan adalah upaya pencegahan penyakit dan atau gangguan kesehatan dari faktor resiko lingkungan untuk mewujudkan kualitas lingkungan yang sehat baik dari aspek fisik, kimia, biologi, maupun sosial (Peraturan Pemerintah Republik Indonesia Nomor 66 Tahun 2014).
Menurut Millennium Development Goals (MDGs) tahun 2015 butir 7 dengan tujuan memastikan kelestarian lingkungan, dalam hal ini terkait dengan kesehatan lingkungan. Salah satu cara untuk mencapai tujuan tersebut adalah melalui penyehatan air dan pengolahan limbah cair. 
Limbah yang dihasilkan dari kegiatan produksi memberikan dampak negatif terhadap lingkungan. Salah satunya berupa pencemaran air yang berpengaruh terhadap kesehatan manusia. Indonesia merupakan negara berkembang yang sebagian besar produksi limbahnya berasal dari aktivitas masyarakat dalam bentuk limbah cair industri. Air limbah adalah sisa dari suatu hasil usaha dan atau kegiatan yang berwujud cair (Peraturan Daerah Propinsi Jawa Tengah Nomor 5 Tahun 2012). Kini jumlah penyakit berbasis lingkungan banyak dijumpai dikalangan masyarakat. Salah satu penyebabnya adalah pencemaran air akibat hygiene sanitasi masyarakat yang buruk.Sebagai contoh banyak ditemukan industri tahu yang langsung membuang limbah cair hasil pengolahan tahunya ke badan air.

Tahu merupakan makanan tradisional dengan kandungan gizi yang baik, berbahan dasar kedelai (Glysine spp) dan sangat digemari oleh seluruh lapisan masyarakat Indonesia. Saat ini pembuatan tahu di Indonesia masih menggunakan teknologi yang sederhana, sehingga tingkat efisiensi penggunaan sumber daya (air dan bahan baku) masih sangat rendah dan tingkat produksi limbahnya sangat tinggi. Dalam proses pembuatan tahu, setiap tahapannya menggunakan air sebagai bahan pembantu dalam jumlah yang banyak. Setiap $1 \mathrm{~kg}$ bahan baku kedelai dibutuhkan rata-rata 45 liter air dan akan dihasilkan limbah cair berupa whey tahu rata-rata 43,5 liter (Nuraida, 1985). Whey mengandung bahan-bahan organik berupa protein, karbohidrat dan lemak tinggi (Nurhasan dan Pramudyanto, 1987).Limbah tersebut dapat segera terurai di lingkungan menjadi senyawasenyawa organik yang dapat mencemari lingkungan.Limbah cair industri tahu mengandung BOD, COD, TSS, Nitrogen dan Fosfor tinggi.Jumlah industri tahu di Indonesia pada tahun 2010 mencapai 84.000 unit usaha. Dengan kapasitas produksi lebih dari 2,56 juta ton per tahun, industri tahu ini memproduksi limbah cair sebanyak 20 juta meter kubik per tahun. Sebagian besar industri tahu yang ada di Indonesia merupakan industri berskala kecil dan menengah yang belum mengelola limbahnya secara baik.Data tersebut dapat dibayangkan betapa banyaknya limbah cair industri tahu yang dibuang ke lingkungan dan berpotensi menimbulkan pencemaran. (Ardhaningtyas, 2012, h. 1)

Tanaman hias jenis Equisetum hyemale memiliki kinerja yang cukup baik dalam pengolahan air limbah dengan sistempengolahan lahan basah buatan aliran bawah permukaan (SSF-Wetlands). Menurut hasil pengukuran salah satu parameter limbah domestik yaitu tanaman Bambu Air memiliki efisiensi penurunan kadar BOD rata-rata $86 \%$ dan COD $84 \%$. Sistem pengolahan lahan basah buatan aliran bawah permukaan (SSF-Wetlands) merupakan salah satu sistim pengolahan limbah yang efektif dan efisien dibuktikan dengan biaya pembangunan dan operasional yang relatif lebih murah, mudah dioperasikan dan dirawat, serta relatif toleran terhadap berbagai tingkat konsentrasi bahan pencemar termasuk logam berat dan senyawa beracun. (Riswahyudi, 2010)

Berdasarkan studi pendahuluan, kondisi pabrik tahu di Desa Prembun tidak memiliki IPAL (Instalasi Pengolahan Air Limbah). Kapasitas produksi pabrik tahu di Desa Prembun lebih dari $100 \mathrm{~kg}$ kedelai per hari, setiap $1 \mathrm{~kg}$ kedelai dibutuhkan 43 liter air dan akan dihasilkan limbah cair berupa whey tahu sebanyak 40 liter sehingga limbah cair berupa whey yang dihasilkan per hari adalah 4 meter kubik yang langsung dibuang ke badan air sehingga mengakibatkan terjadinya pencemaran lingkungan, maka dari itu peneliti merancang alat pengolah limbah berupa Subsurface Flow Wetlands dengan media tanaman Bambu Air (Equisetum hyemale) di pabrik tahu tersebut. Harapannya jika rancangan alat ini berhasil, maka permasalahan yang ada di pabrik tahu kaitan dengan pencemaran akibat pengolahan limbah tahu yang tidak benar dapat teratasi, sehingga resiko untuk terpapar penyakit yang berbasis air dapat terkurangi, lingkungan menjadi lebih bersih, tidak berbau dan bebas dari penularan penyakit.

\section{METODE}

Penelitian ini menggunakan jenis penelitian eksperimen semu dengan metode pre and post test design, dengan maksud untuk mengetahui ada atau tidak adanya perbedaan konsentrasi BODsebelum dan sesudah pemakaian tanaman Bambu air (Equisetum hyemale) dengan media Subsurface Flow Wetlands (SSF-Wetlands).

\section{III.HASIL DAN PEMBAHASAN}

\section{Hasil}

Proses pengukuran parameter suhu, $\mathrm{pH}$, debit, dan $\mathrm{BOD}_{5}$ dilakukan setelah waktu tinggal limbah 3 hari pada waktu pagi hari dengan kondisi cuaca cerah. Teknis pelaksaan penelitian yaitu dengan melakukan pengambilan sampel influent replikasi sebanyak 3 sampel, sampel effluent replikasi sebanyak 3 sampel, 1 sampel influent kontrol dan 1 sampel effluent kontrol.

Pengukuran parameter suhu dan $\mathrm{pH}$ dilakukan secara langsung di lokasi pengambilan sampel yaitu di pabrik tahu milik Bapak Heri Santoso. Pengukuran debit dilakukan pada saat awal penelitian yaitu sebelum merancang alat peneliti melakukan pengukuran debit limbah tahu yang dihasilkan setiap hari, sedangkan pengukuran debit limbah pada bak ekualisasi menuju ke proses pengolahan di bak Subsurface Flow Wetlands dilakukan setelah rancangan alat Subsurface Flow Wetlands siap untuk digunakan dan pengukuran debit effluent atau debit setelah perlakuan dilakukan pada saat peneliti melakukan pengambilan sampel effluent. Pemeriksaan parameter $\mathrm{BOD}_{5}$ dilakukan di Laboratorium Kesehatan Purbalingga dengan cara pengambilan sampel menggunakan botol winkler 
untuk sampel $\mathrm{BOD}_{5}$. Sampel $\mathrm{BOD}_{5}$ dibawa dari lokasi menuju laboratorium menggunakan ice box yang berisi es batu, hal ini dilakukan untuk menghambat pertumbuhan bakteri pada sampel tersebut. Berikut ini adalah hasil pengukuran tiap parameter limbah tahu:

1. Suhu

Hasil pengukuran suhu influent kontrol sebesar $30,3{ }^{\circ} \mathrm{C}$ sedangkan suhu effluent kontrol sebesar $28,0{ }^{\circ} \mathrm{C}$, dari hasil pengukuran suhu kontrol atau tanpa perlakuan.Hasil penelitian menggunakan tanaman Bambu air (Equisetum hymale) dengan media Subsurface Flow Wetlands dengan replikasi sampel sebanyak 3 kali pengukuran setelah 3 hari masa waktu tinggal menunjukkan, bahwa sebelum mengalami proses pengolahan menggunakan Subsurface Flow Wetlands suhu influent rata-rata air limbah pembuatan tahu sebesar $30,2{ }^{\circ} \mathrm{C}$. Hasil proses pengolahan menggunakan Subsurface Flow Wetlands suhu effluent rata-rata air limbah pembuatan tahu sebesar $26,1^{\circ} \mathrm{C}$.

2. Derajat Keasaman $(\mathrm{pH})$

Hasil pengukuran $\mathrm{pH}$ influent sebesar 3,87 sedangkan $\mathrm{pH}$ effluent kontrol sebesar 5,42, dari hasil pengukuran $\mathrm{pH}$ kontrol atau tanpa perlakuan $\mathrm{pH}$ mengalami perubahan derajat keasaman, $\mathrm{pH}$ air limbah masih bersifat asam karena nilai $\mathrm{pH}$ belum menunjukkan pada kisaran 6-9 atau $\mathrm{pH}$ air bersifat netral.Hasil penelitian menggunakan tanaman Bambu air (Equisetum hymale) dengan media Subsurface Flow Wetlands dengan replikasi sampel sebanyak 3 kali pengukuran setelah 3 hari masa waktu tinggal menunjukkan, bahwa sebelum mengalami proses pengolahan menggunakan tanaman Bambu air (Equisetum hymale) dengan media Subsurface Flow Wetlands $\mathrm{pH}$ influent rata-rata air limbah pembuatan tahu sebesar 3,82 sehingga air limbah masih bersifat asam. Hasil proses pengolahan menggunakan Subsurface Flow Wetlands $\mathrm{pH}$ effluent rata-rata air limbah pembuatan tahu sebesar 7,95 sehingga air limbah bersifat netral, dari hasil pengukuran $\mathrm{pH}$ dengan menggunakan perlakukan, $\mathrm{pH}$ mengalami peningkatan yaitu $\mathrm{pH}$ sebelum perlakuan sebesar 3,82 dan $\mathrm{pH}$ setelah perlakuan sebesar 7,95. Hal ini dapat diasumsikan bahwa alat yang peneliti rancang dapat mengubah $\mathrm{pH}$ air yang asam menjadi netral.

3. Waktu Tinggal

Pengukuran waktu tinggal atau waktu detensi ( $\Theta=V / Q$ ) yaitu perbandingan antara volume limbah cair yang masuk kedalam alat Subsurface Flow Wetlands dibagi dengan debit influent limbah cair.Hasil pengukuran waktu tinggal adalah 4.320 menit atau 3 hari.

4. Debit

Pengukuran debit didapat dengan cara menggunakan rumus $Q=V / t$, dengan keterangan rumus yaitu $Q$ adalah debit limbah (liter/menit),
$V$ adalah Volume (liter) dan $t$ adalah waktu (menit). Debit yang diukur yaitu debit pada saat limbah cair hasil pengolahan tahu yang pertama kali masuk ke dalam bak ekualisasi, debit limbah dari bak ekualisasi menuju ke proses pengolahan limbah menggunakan Subsurface Flow Wetlands dan pengukuran debit effluent limbah cair setelah mengalami proses pengolahan. Hasil pengukuran debit saat limbah cair hasil pengolahan tahu yang pertama kali masuk ke dalam bak ekualisasi sebesar 0,22 liter/menit, debit limbah dari bak ekualisasi menuju ke proses pengolahan limbah menggunakan Subsurface Flow Wetlands sebesar $0,083 \mathrm{ltr} / \mathrm{menit}$ dan pengukuran debit effluent limbah cair setelah mengalami proses pengolahan 0,020 liter/menit.

5. BOD (Biological Oxygen Demand)

a. Pemeriksaan Laboratorium

Pemeriksaan sampel BOD $_{5}$ dilakukan di Laboratorium Kesehatan Purbalingga, Dinas Kesehatan Kabupaten Purbalinngga dengan hasil pengukuran BOD $_{5}$ influent kontrol sebesar 15.359,38 mg/liter dan effluent kontrol sebesar 15.334,32 dari hasil pengukuran $\mathrm{BOD}_{5}$ kontrol atau tanpa perlakuan $\mathrm{BOD}_{5}$ mengalami efisiensi penurunan sebesar $0,16 \%$.Hasil pemeriksaan sampel $\mathrm{BOD}_{5}$ setelah air limbah mengalami proses perlakuan menggunakan Subsurface Flow Wetlands dengan replikasi sampel sebanyak 3 kali pengukuran setelah 3 hari masa waktu tinggal menunjukkan, bahwa sebelum mengalami proses pengolahan menggunakan Subsurface Flow Wetlands, BODsinfluent rata-rata air limbah pembuatan tahu sebesar $15.611,56 \mathrm{mg} / \mathrm{liter}$ namun setelah mengalami proses pengolahan menggunakan Subsurface Flow Wetlands $\mathrm{BOD}_{5}$ effluent rata-rata air limbah pembuatan tahu sebesar 1.561,16 $\mathrm{mg} /$ liter sehingga hasil perlakuan sampel $\mathrm{BOD}_{5}$ menggunakan Subsurface Flow Wetlands mengalami efisiensi penurunan ratarata sebesar $89,99 \%$.

b. Analisis Statistik

Analisis statistik yang peneliti gunakan untuk mengetahui perbedaan penggunaan Subsurface Flow Wetlands terhadap penurunan konsentrasi $\mathrm{BOD}_{5}$ pada industri pengolahan tahu adalah menggunakansoftware SPSS versi 17 dan dianalisis secara statistik dengan uji paired t-test.Hasil analisis statistik menggunakan uji paired t-test menghasilkan nilai signifikan $(P$ Value $)$ sebesar 0.000 , yang artinya nilai sig $(P$ value $)<\alpha(0.05)$ sehingga terdapat perbedaan yang signifikan antara hasil pemeriksaan $\mathrm{BOD}_{5}$ sebelum dan hasil pemeriksaan $\mathrm{BOD}_{5}$ sesudah melalui proses pengolahan limbah tahu menggunakan Subsufarce Flow Wetlands. 


\section{Pembahasan}

Hasil penelitian menggunakan tanaman Bambu air (Equisetum hymale) dengan media Subsurface Flow Wetlands dengan sampel replikasi sebanyak 3 kali pengukuran setelah 3 hari menunjukkan, bahwa sebelum mengalami proses pengolahan menggunakan Subsurface Flow Wetlands suhu influent rata-rata air limbah pembuatan tahu sebesar $30,2{ }^{\circ} \mathrm{C}$ sedangkan suhu effluent rata-rata air limbah tahu sebesar 26,1 ${ }^{\circ} \mathrm{C}$ sehingga suhu air limbah memenuhi persyaratan baku mutu air limbah menurut Peraturan Daerah Propinsi Jawa Tengah Nomor 5 Tahun 2012 Tentang Baku Mutu Air Limbah dengan batas maksimum suhu sebesar $38^{\circ} \mathrm{C}$.

Pengukuran parameter $\mathrm{pH}$ sebelum mengalami proses pengolahan menggunakan Subsurface Flow Wetlands menghasilkan $\mathrm{pH}$ influent rata-rata sebesar 3,82 sehingga $\mathrm{pH}$ air limbah tidak memenuhi persyaratan baku mutu air limbah menurut Peraturan Daerah Propinsi Jawa Tengah Nomor 5 Tahun 2012 Tentang Baku Mutu Air Limbah dengan kadar kisaran pH yang dipersyaratkan sebesar 6-9. Pengukuran parameter $\mathrm{pH}$ setelah mengalami proses pengolahan menggunakan Subsurface Flow Wetlands menghasilkan $\mathrm{pH}$ effluent rata-rata air limbah sebesar 7,95 sehingga $\mathrm{pH}$ air limbah memenuhi persyaratan baku mutu air limbah menurut Peraturan Daerah Propinsi Jawa Tengah Nomor 5 Tahun 2012 Tentang Baku Mutu Air Limbah dengan kadar kisaran $\mathrm{pH}$ yang dipersyaratkan sebesar 6-9.

Hasil penelitian tanpa perlakuan atau sampel kontrol yaitu mengolah limbah pembuatan tahu tanpa menggunakan media tanaman bambu air (Equisetum hymale) dengan mengambil 1 sampel influent dan 1 sampel effluent dengan waktu tinggal selama 3 hari menunjukkan, bahwa suhu influent air limbah pembuatan tahu sebesar $30,3^{\circ} \mathrm{C}$ sedangkan suhu effluent air limbah pembuatan tahu sebesar 28,0 sehingga suhu air limbah memenuhi persyaratan baku mutu air limbah menurut Peraturan Daerah Propinsi Jawa Tengah Nomor 5 Tahun 2012 Tentang Baku Mutu Air Limbah dengan batas maksimum suhu sebesar $38^{\circ} \mathrm{C}$.. Pengukuran $\mathrm{pH}$ influent sebesar 3,87 sedangkan $\mathrm{pH}$ effluent air limbah pembutan tahu sebesar 5,42 sehingga $\mathrm{pH}$ air limbah tidak memenuhi persyaratan baku mutu air limbah menurut Peraturan Daerah Propinsi Jawa Tengah Nomor 5 Tahun 2012 Tentang Baku Mutu Air Limbah dengan kadar kisaran $\mathrm{pH}$ yang dipersyaratkan sebesar 6-9.

Menurut Peraturan Daerah Propinsi Jawa Tengah Nomor 5 Tahun 2012 Tentang Baku Mutu Air Limbah, kadar maksimum $\mathrm{BOD}_{5}$ pada limbah tahu yaitu sebesar $150 \mathrm{mg} / \mathrm{liter}$. Hasil pemeriksaan $\mathrm{BOD}_{5}$ setelah melalui proses pengolahan menggunakan Subsurface Flow Wetlands dengan media tanaman berupa bambu air (Equisetum hymale) menghasilkan kadar $\mathrm{BOD}_{5}$ sebesar 1.561,16 $\mathrm{mg} / \mathrm{liter}$ dengan efisiensi penurunan sebesar $89,99 \%$. Hasil pemeriksaan $\mathrm{BOD}_{5}$ tersebut dapat diketahui bahwa kadar $\mathrm{BOD}_{5}$ setelah proses pengolahan masih belum memenuhi persyaratan baku mutu air limbah tahu sesuai dengan Peraturan Daerah Propinsi Jawa Tengah Nomor 5 Tahun 2012 Tentang Baku Mutu Air Limbah dikarenakan hasil pengolahan limbah tersebut masih di atas kadar maksimum yang ditetapkan yaitu sebesar $150 \mathrm{mg} /$ liter.

Menurut Bowo Marsono (1998) menyatakan efisiensi penurunan $\mathrm{BOD}_{5}$ sebesar $80 \%-90 \%$ sehingga untuk efisiensi penurunan $\mathrm{BOD}_{5}$ telah memenuhi persyaratan efisiensi penurunan unit operasi pengolahan limbah cair dikarenakan hasil efiensi penurunan $\mathrm{BOD}_{5}$ menggunakan tanaman Bambu air (Equisetum hymale) dengan media Subsurface Flow Wetlands sebesar 89,99\%.. Hasil perhitungan $\mathrm{BOD}_{5}$ dengan analisis statistik menggunakan uji paired t-test menghasilkan nilai signifikan $(P$ Value $)$ sebesar 0.000 , yang artinya nilai sig $(P$ value $)<\alpha(0.05)$ sehingga $H_{0}$ ditolak artinya terdapat perbedaan yang signifikan penggunaan tanaman bambu air (Equisetum hymale) dengan media Subsurface Flow Wetland terhadap penurunan konsentrasi $\mathrm{BOD}_{5}$ yang signifikan antara hasil pemeriksaan $\mathrm{BOD}_{5}$ sebelum dan hasil pemeriksaan $\mathrm{BOD}_{5}$ sesudah melalui proses pengolahan limbah tahu menggunakan tanaman bambu air (Equisetum hymale) dengan media Subsufarce Flow Wetlands.

\section{IV.SIMPULAN DAN SARAN}

Berdasarkan hasil penelitian dan pembahasan, maka penelitian ini dapat diambil kesimpulan kadar $\mathrm{BOD}_{5}$ inlet limbah cair industri tahu sebesar 15.611,56 mg/liter sedangkan kadar $\mathrm{BOD}_{5}$ outlet limbah cair industri tahu sebesar $1.561,16 \mathrm{mg} / \mathrm{liter}$. Uji paired $t$-test menghasilkan nilai sig. sebesar 0.000 yang artinya nilai sig $(P$ value $)<\alpha(0.05)$ sehingga terdapat perbedaan yang signifikan penggunaan tanaman Bambu Air (Equisetum hymale) dengan media Subsurface Flow Wetlands terhadap penurunan kadar BOD limbah tahu. Efisiensi penurunan kadar $\mathrm{BOD}_{5}$ sebelum dan sesudah mengalami perlakuan menggunakan tanaman Bambu Air (Equisetum hymale) dengan media lahan basah buatan aliran bawah permukaan (Subsurface Flow Wetlands) sebesar $89,99 \%$.

Pemilik usaha industri pembuatan tahu diharapkan membuat IPAL sederhana salah satunya dengan menggunakan tanaman bambu air dengan media Subsurface Flow Wetlands untuk mengolah limbah cair hasil pembuatan tahu, hal ini bertujuan supaya resiko pencemaran melalui air akibat limbah cair dari hasil proses pengolahan tahu dapat diminimalisir.

Dinas kesehatan diharapkan dapat melakukan sosialisasi tentang pengolahan limbah cair industri tahu dengan menggunakan tanaman Bambu Air (Equisetum hymale) dengan media Subsurface Flow Wetlands kepada para pemilik usaha pembuatan tahu, hal ini bertujuan untuk meningkatkan pengetahuan para pemilik usaha dalam melakukan proses pengolahan limbah cair. 
Diharapkan bagi para penelitian lain untuk merancang ulang alat tersebut diantaranya: Memperluas ukuran bak Subsurface Flow Wetlands supaya proses pengolahan limbah cair dapat berlangsung lebih baik dan efisien, memperpanjang lama tinggal limbah yaitu lebih dari 3 hari, hal ini bertujuan untuk proses penguraian bahan organik oleh bakteri di dalam bak Subsurface Flow Wetlandsdapat berlangsung lebih efisien, menambah jumlah tanaman Bambu air (Equisetum hymale), hal ini bertujuan supaya proses penguraian zat kontaminan pada air limbah oleh akar tanaman Bambu air (Equisetum hymale) di dalam bak Subsurface Flow Wetlands dapat berlangsung lebih baik dan efisien.

\section{UCAPAN TERIMAKASIH}

Ucapan banyak terimakasih disampaikan kepada pemilik pabrik tahu di Desa Prembun, Kecamatan Tambak, Kabupaten Banyumas dan semua pihak yang tidak dapat disebutkan satu persatu yang telah membantu dalam menyelesaikan Karya Tulis Ilmiah ini sehingga penelitian ini dapat segera diselesaikan.

\section{DAFTAR PUSTAKA}

Agus Wediyanto, 2007, Standar Operasional Prosedur (SOP) Sansevieria trifasciata "lorentii", Direktorat Jenderal Hortikultura Departemen Pertanian.

Anonim, 1998, Design Manual : Constructed Wetlands and Aquatic Plant System for Municipal Wastewater Treatment, Office of Research and Development, U.S. EPA, Cincinnati, OH: USA.

Ardhaningtyas Riza Utami, 2012, Analisa Ekstraksi Biogas Dari Limbah Cair Tahu Dengan Menggunakan Bioreaktor Anaerobik Berbahan Aditif Eceng Gondok Dalam Laporan Tugas Akhir, Surabaya: ITS.

Aris Santjaka, 2011, Statistik untuk Penelitian Kesehatan 1, Yogyakarta: Nuha Medika.

Badan Pengkajian dan Penerapan Teknologi, 1999, Materi Pelatihan Teknologi Pengolahan Air Bersih, Pusat Teknologi Lingkungan Deputi Bidang Teknologi Pengelolaan Sumber Daya Alam Badan Pengkajian dan Penerapan Teknologi

Bowo Marsono, 1998, Unit Operasi, Institut Teknologi Surabaya, Surabaya.

Crites, R. and George Tchobanoglaus, 1998, Small and Decentralized Wastewater Management Systems : Wetlands and Aquatic Treatment Systems, Mc Graw-Hill, Singapore.
Djamaluddin Ramlan, Suparmin dan Febri Apwanti, 2013, Pedoman Praktikum Laboratorium Kesehatan Lingkungan, Purwokerto: Laboratorium Kesehatan Lingkungan Poltekkes Kemenkes Semarang Jurusan Kesehatan Lingkungan Purwokerto.

E.B, Welch, 1992, Carbon,Nitrogen and Sulfur Pollutants and Their Determination In Air and Water, New York: Marcel Dekker, INC.

Effendi, H., 2003, Telaah Kualitas Air : Bagi Pengelolaan Sumber Daya dan Lingkungan Perairan, Penerbit Kanisius, Yogyakarta.

Greyson, 1990, Ecological Effect of Wastewater: Applied Limonology and Pollution Effect, London, New York: E \& FN Spon

Haberl, R dan Langergraber, H, 2002, Constructed Wetlands a Chance to Solve Wastewater Problems in Developing Countries, Wat Sci: Tecnol 40.

Halverson, Nancy V., 2004, Review of Constructed Subsurface Flow vs. Surface Flow Wetlands, U.S. Department of Energy, Springfield: USA.

Heru Dwi Wahjono, Nusa Idaman Said dkk, 1999, Teknologi Pengolahan Air Limbah TahuTempe Dengan Proses Biofilter Anaerob dan Aerob; Jakarta: Kelompok Teknologi Pengolahan Air Bersih dan Limbah Cair Direktorat Teknologi Lingkungan, Deputi Bidang Teknologi Informasi, Energi, Material dan Lingkungan Badan Pengkajian dan Penerapan Teknologi.

Heru Dwi Wahjono, Nusa Idaman Said dkk, 1999, Teknologi Pengolahan Air Limbah TahuTempe Dengan Proses Biofilter Anaerob dan Aerob; Jakarta: Kelompok Teknologi Pengolahan Air Bersih dan Limbah Cair Direktorat Teknologi Lingkungan, Deputi Bidang Teknologi Informasi, Energi, Material dan Lingkungan Badan Pengkajian dan Penerapan Teknologi.

Heyne, K. 1987. Tumbuhan Berguna Indonesia.Jilid 1. Yayasan Sarana Wana Jaya. Jakarta.

Hindarko, S., 2003, Mengolah Air Limbah : Supaya Tidak Mencemari Orang Lain, Penerbit ESHA, Jakarta.

Husin, 2003, Pengolahan Limbah Cair Tahu Menggunakan Biji Kelor (Moringa Oleifera Seeds) Sebagai Koagulan, Laporan Penelitian Dosen Muda, Fakultas Teknik USU. 
Indonesia, 2000, MDGs (Millenium Development Goals), Jakarta: Unicef.

Khiatudddin, 2003, Melestarikan Sumber Daya Air dengan Teknologi Rawa Buatan, Yogyakarta: Gajah Mada University, University Press.

Kimball, John W, 1999. Biologi Jilid 3, Jakarta : Erlangga

Leady, 1997.Pengolahan Limbah Cair Dengan Tumbuhan, Jakarta : Erlangga

Melithia,C. L.A. Jhonson, dan W. Amber. 1996. Ground Water Polution: In situ Biodegradation. Down loading, available at http:www.cee. vt.edu/program_areas/ enviromental teach/gwprimer/group1 / ind /ex /html diakses pada tanggal 8 Februari 2014 pukul 20.00 WIB

Nuraida, 1985, Analisis Kebutuhan Air Pada Industri Pengolahan Tahu dan Kedelai, dalam Lisnasari, S.F., 1995, Pemanfaatan Gulma Air (Aquatic Weeds) Sebagai Upaya Pengolahan Limbah Cair Industri Pembuatan Tahu. Thesis Master, Program Pasca Sarjana USU, Medan.

Nurhasan dan B. Pramurdyanto, 1987, Pengolahan Air Buangan Industri Tahu, Semarang: Yayasan Bina Lestari dan WALHI.

Peraturan Daerah Propinsi Jawa Tengah Nomor 5 Tahun 2012 Tentang Baku Mutu Air Limbah.

Peraturan Pemerintah Republik Indonesia Nomor 66 Tahun 2014 Tentang Kesehatan Lingkungan.

Riswahyudi, 2010, Pengolahan Limbah Domestik Menggunakan Tanaman Hias Equisetum hyemale, Dalam Sistem Lahan Basah Buatan Aliran Bawah Permukaan (SSFWetlands)Dalam Tesis, Semarang: Universitas Diponegoro.

Soeparman dan Suparmin, 2000, Pembuangan Tinja dan Limbah Cair, Jakarta: EGC.
Sugiharto,1987.Dasar-Dasar Pengolahan Air Limbah.Edisi 1. Jakarta: Universitas Indonesia.

Supradata, 2005, Pengolahan Limbah Domestik Menggunakan Tanaman Hias Cyperus alternifolius, Dalam Sistem Lahan Basah Buatan Aliran Bawah Permukaan (SSFWetlands)Dalam Tesis, Semarang: Universitas Diponegoro.

Suriawiria, U., 1993, Mikrobiologi Air, Penerbit Alumni, Bandung.

Tangahu, B.V. dan Warmadewanthi, I.D.A.A., 2001, Pengelolaan Limbah RumahTangga Dengan Memanfaatkan Tanaman Cattail (Typha angustifolia) dalam Sistem Constructed Wetland, Purifikasi, Volume 2 Nomor 3, ITS - Surabaya.

Tay, Joo-Hwa, 1990,Biological Treatment of Soya Bean Waste, J. Water Science and Technology, Vol.22. No. 9 : 141-147.

Tjitrosoepomo, Gembong. 1989. Taksonomi Tumbuhan. Yogyakarta : Gajah Mada University Press

Tjitrosomo, Siti Sutarmi. 1983. Botani Umum. Yogyakarta : Gajah Mada University Press

Tri Cahyono, 2013, Pedoman Penulisan Proposal Penelitian dan Karya Tulis Ilmiah / Skripsi, Edisi Revisi $\mathrm{Ke}$ 3, Purwokerto: Poltekkes Kemenkes Semarang Jurusan Kesehatan Lingkungan Purwokerto.

Van Steenis. C.G.G. J. 1992. Flora. PT Pradya Paramita. Jakarta

Widiarni Anugrah Safitri, 2012, Studi Kinerja Unit Pengolahan Limbah Cair Batik Dengan Sistim Lahan Basah Buatan Kelurahan Jenggot Kecamatan Pekalongan Kota Pekalongan DalamKarya Tulis Ilmiah, Purwokerto: Poltekkes Kemenkes Semarang Jurusan Kesehatan Lingkungan Purwokerto. 